\title{
La parodia y la sátira en la historieta transpositiva de Alberto Breccia
}

\section{Caraballo, Laura}

Resumen:

Este artículo propone algunas pistas de análisis de ciertos aspectos genéricos de la obra transpositiva de Alberto Breccia. Específicamente se aborda el modo en que el autor -sobre la base de elementos temáticos del fantástico- realiza un movimiento paródico y satírico. El corte realizado en el corpus de su obra destaca aquellas historietas resultado de una transposición de relatos literarios a la historieta. El concepto de género se extiende a su vez de la literatura a otros dispositivos, como la historieta, permitiéndonos situar estas obras ( $\mathrm{y}$ no solamente los textos literarios que las inspiran) dentro de lo fantástico y lo maravilloso. Breccia opera en su trabajo una transposición de lo fantástico a la imagen, siendo este

Cuadernos del Centro de Estudios de Diseño y Comunicación №74

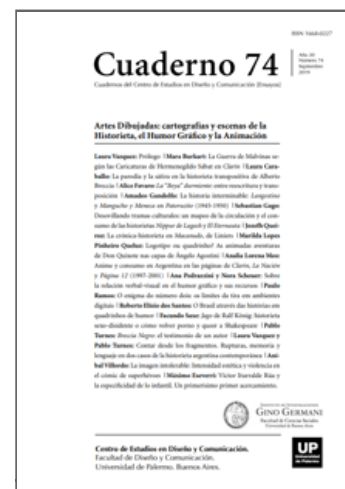

ISSN: 1668-0227

Artes Dibujadas:

cartografías y

escenas de la

Historieta, el Humor

Gráfico y la

Animación

Año XX, Septiembre 2019, Buenos

Aires, Argentina | 256 páginas

descargar PDF ver índice de la publicación

Ver todos los libros de la publicación

compartir en Facebook

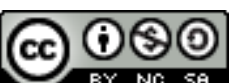

Esta obra está bajo una Licencia Creative Commons Atribución-NoComercialCompartirlgual 4.0 Internacional género un denominador común de su obra transpositiva.

Palabras clave: Alberto Breccia - transposición - fantástico - sátira.

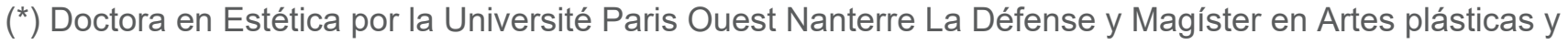
ciencias del arte por la Ecole Normale Supérieure de Lyon. Cursó su Licenciatura en Historia del Arte en la Universidad Nacional de La Plata.

Del género fantástico a la parodia y la sátira

La inscripción de la obra de Breccia en el género fantástico constituye un parámetro para analizar el detonante de una nueva forma plástica. Breccia comienza a repensar el dispositivo a partir de su colaboración con Hector German Oesterheld, con historietas que pueden situarse en ese género. Igualmente, en la etapa en que la 
mayor experimentación formal tiene lugar en sus transposiciones, sus elecciones temáticas se mantienen casi invariables. De este modo, al momento de realizar las transposiciones, Breccia eligió clásicos literarios vinculados a lo fantástico, lo maravilloso, a la literatura gótica y de horror. El mismo ha afirmado, en efecto, que ese campo genérico le permitió hacer sus búsquedas plásticas e ir mas allá de la representación figurativa. En sus palabras, el fantástico constituye un clic que lo lleva a una búsqueda centrada en la puesta en imágenes, permitiendo explorar ese dominio mas allá de los bordes de la verosimilitud historietística y el realismo figurativo. Analizaremos la distancia que toma Breccia al trasponer a través de un enfoque irónico y cómico. El dibujante opera, en este sentido, un desdoblamiento en la transposición.

Transpone visualizando (literatura - secuencia de imágenes) y realiza un segundo desvío, el de la parodia y la sátira. Situamos aquí los análisis correspondientes a estas categorías, ya que la parodia puede concebirse, como el fantástico, como un género que se materializa tanto en el contenido temático como a través de los elementos plásticos y representativos. Si bien los textos-fuente de las historietas transpositivas de Alberto Breccia pertenecen en su mayoría a la misma familia genérica del fantástico y lo maravilloso, no se trata en ningún caso de un conjunto coherente y cerrado, sino de un ensamble dinámico. Las historietas de Breccia son fantásticas pero poseen elementos y cumplen con propiedades de otros géneros, como el cómico y lo grotesco, que usualmente no asociamos al fantástico, pero que comportan del mismo modo una licencia de deformación y de transposición de la realidad considerada "ordinaria". En ambos casos se trata de un franqueo del realismo. El análisis de la obra de Breccia nos permite, entonces, sugerir una afinidad entre el fantástico y la comedia, entre otras cosas, mediante la caricatura.

Si la parodia como género implica retomar un discurso precedente, esta dimensión se suma y redobla, como dijimos, el enfoque transpositivo del texto a la imagen-secuencia. Se opera en efecto un desdoblamiento de la transposición: la primera es una puesta en imágenes (literatura-historieta), la segunda es un pasaje al burlesco.

Una definición sumaria de la parodia evocará precisamente lo cómico como principio de ese desdoblamiento: "Imitación consciente y voluntaria, sea de fondo, sea de la forma, en una intención burlona o simplemente cómica"1 Vale decir, que del mismo modo que sucedió con la historieta, el aspecto cómico de la parodia la ha relegado a género menor o divertimento en relación a la gravedad y "seriedad" de la tragedia. Pero seguramente esa condición de menor constituya el valor y riqueza de estas artes.

Desplegando los recursos de lo cómico, la historieta ha sido susceptible a lo largo de su historia a las influencias caricatura, el film burlesco y la literatura satírica, engendrando, a su vez, formas de humor propias. En sus inicios, confinada a la ultima pagina del periódico, estaba reservada al divertimento, su objetivo principal siendo la eficacia de una respuesta ideal del lector: la risa. Lo cómico busca asimismo esa eficacia directa, una mala broma no hace reír. Es en este sentido que Henri Bregson busca definir lo cómico, en su relación indefectible con la existencia humana y social: “Un paisaje podrá ser bello, agradable, sublime, insignificante o feo ; no será nunca risible"2. No disfrutaríamos de lo cómico si estuviéramos aislados; la risa necesita de un eco. Para existir, debe tener un significado social y apoyarse en una serie de referencias compartidas.

Atraído por esta dimensión irónica y ridícula, Breccia no tuvo, al principio de su carrera como dibujante, la intención de hacer historietas serias de dibujo naturalista. Pero si las realizó, a título de trabajo de subsistencia, por ejemplo en sus colaboración con la editorial Manuel Láines y con las revistas Paturuzito y Aventuras. Pero afirmó siempre haber buscado mantener lo caricatural en su trabajo3. Un gusto por el genero humorístico se 
mantiene presente en su obra transpositiva que fue habitualmente resultado de elecciones personales y no de editores, lo que dio lugar a una gran libertad creativa. Esta tendencia aparece bajo diversas configuraciones, especialmente en lo caricatural, en las figuras excesivas, que emergen de una cierta crueldad, presente visualmente y que responde a lo grotesco de las historias elegidas para transponer.

Son, en sus palabras4, las historias que lo llevan sobre la vía formal del grotesco. Breccia nos comparte un cierto determinismo de los textos o guiones a transponer, como si las posibilidades estilísticas del texto-fuente fueran taxativas. Es decir, que cuando Breccia se refiere a sus transposiciones, no considera, por ejemplo, la voluntad de un editor, sino simplemente la fuerza propia de las historias que él recrea en imágenes. Y nos explica también los vínculos entre fantástico, humor, caricatura y experimentación en historieta: esas historias imponen la articulación de nuevos medios, estrictamente historietísticos, precisamente porque éstas se sitúan en las aristas del realismo.

El distanciamiento de la parodia, ironía y la sátira

La ironía aparece en la parodia como un mecanismo retórico que busca activar la toma de consciencia del lector, que deviene de algún modo un "descodificador" 5 . A diferencia de otros tipos de alusión que puede hacer un discurso a otros que lo preceden, la parodia conlleva una distancia crítica manifestada en la ironía. Esta implica una cierta perspectiva que sucede tanto del lado del productor como del receptor.

Si bien sus orígenes en tanto género o procedimiento se remontan a la Antigüedad, la parodia expresa una forma de autoreflexión muy extendida en la modernidad. La vasta literatura sobre la parodia en diferentes épocas y diferentes sitios pone de manifiesto que no existe ninguna definición trans-histórica y unitaria. Actualmente, una caracterización suficientemente amplia se adaptará a practicas contemporáneas en las diferentes artes. Linda Hutcheon ve a la parodia como una forma de inter-art discours, ampliando el concepto mas allá de la literatura para cubrir necesidades del arte moderno y contemporáneo que implican nuevas apropiaciones textuales.

La parodia tiene sus raíces en las nuevas practicas decimonónicas como por ejemplo la literatura en segundo grado: hacia fines del Romanticismo como paradigma dominante y una vez superados los valores del genio inspirado, concepciones mas artesanales de la literatura como la reescritura o la imitación de modelos reconocidos son vistas como etapas necesarias para la creación. "Luego de haber querido reflejar el yo y después la realidad, la literatura tiende a auto-reflexionarse en una consciencia mas aguda del déjà vu [ya visto] y el déjà lu [ya leído]"6 .

Las parodias de Breccia retoman los textos-fuente siguiendo diferentes enfoques, como por ejemplo como un medio para criticar la realidad social y política de su tiempo, a través de la evocación del horror y la denuncia del terror. El tono irónico, el estilo grotesco de la imagen y la referencia a la actualidad nos lleva a su vez hacia el concepto de la sátira, vista como un genero a través del cual se denuncian por la risa los vicios, abusos y defectos del individuo, la institución o de una categoría social o profesional7 . La naturaleza textual o discursiva de la parodia se diferencia entonces de la sátira, que encuentra su fuente y su objeto en la realidad y la actualidad extra-textuales. No obstante una parodia puede someterse a un objetivo satírico (extra-textual). 
La parodia satírica es entonces definida por Daniel Sangsue como la transformación paródica de un texto con el fin de hacer sátira de un objeto exterior a éste. El recurso a la parodia de la sátira se explica porque aquella constituye un desvío en vistas de evitar, por ejemplo, la censura, reportando indirectamente una parte de responsabilidad de la sátira a la autoridad del texto parodiado y protegiéndose detrás de éste.

Los textos parodiados por Breccia son textos canónicos de la literatura, conocidos por una gran parte del público y se convierten, a causa de su propia notoriedad, en medios seguros y eficaces para vehicular una crítica, una expresión de descontento por la vía satírica. No es casual si esas transposiciones datan de fines de los años 70 y principios de los 80, momentos de transición política y de extrema violencia en Argentina. Esas historias deben ponerse en relación con la actualidad política y social, articulándose con las vivencias de los ciudadanos.

Es el caso de la tansposición del cuento de Edgar Allan Poe, "William Wilson", en que Breccia y Sacomanno transplantan el relato situado en la Inglaterra del siglo XIX al barrio de Mataderos a principios del siglo XX, en medio de las fiestas de Carnaval. La restitución de la historia en el contexto del carnaval constituye un medio para burlar la censura del gobierno militar. Esta fiesta popular es una de las primeras en ser prohibidas por la dictadura. El carnaval siempre tuvo un sentido político fuerte, el de la transgresión temporal del orden establecido, en estrecha relación con lo mundano y lo carnal: es un momento de toma de posesión del espacio público y las transgresiones son autorizadas.

La historieta evoca entonces uno de esos momentos de la manifestación popular contra las autoridades y tematiza, al mismo tiempo, la violencia que reinaba en el país. Breccia y Sacomanno eligen burlarse del régimen militar exaltando el costado prohibido del carnaval y cubriendo a los personajes con grotescas y coloridas máscaras. Por otro lado, lo ridículo llevado por la sátira del carnaval contienen un propósito terapéutico, la puesta en marcha del ridículo funciona como una salida para sanear la agresividad y la revuelta contra el orden establecido, para ofrecer una necesaria libertad de expresión. Estas manifestaciones permiten luego una vuelta a la calma8 . Duval y Martínez toman prestada a Bajtin la visión carnavalesca de la sátira como una forma de vida y un espacio catártico de descarga, un medio para ridiculizar y criticar en un ambiente que lo permite, en este caso, un soporte o dispositivo que lo facilita. En Drácula, Dracul, Vlad ? Bah (transposición de la novela de Bram Stoker), publicada en la vuelta democrática, la indignación y la crítica directa del contexto reciente son simples de descifrar. Breccia visualiza los horrores del terrorismo de estado recurriendo a una imagen tanto estereotipada como grotesca.

Al igual que otros personajes de ficción, Drácula a sido retomado en una diversidad de dispositivos (cine, teatro, comedia musical, etc.). En la transposición de Breccia, el Conde muestra sus colmillos de vampiro y su sed de sangre humana pero se vuelve una criatura en apariencia inofensiva, sobrepasada por el doloroso contexto que lo rodea. Esta historieta constituye una visión significativa en medio de la diversidad de enfoques del célebre personaje. En el marco de la parodia, construye un sujeto grotesco, alienado y perdido, en un contexto que reenvía a un momento preciso de la historia argentina. El héroe deambula en los cinco episodios del álbum en un país devastado por el terror, el hambre y la violencia. A juzgar por el lugar que ocupa en los espacios que recorre y la expresión constantemente sorprendida de su rostro, siempre con ojos grandes y abiertos, juega el rol de testigo y de juez de los acontecimientos sin comprenderlos del todo.

El episodio "Ya no soy leyenda" constituye en ese sentido un retrato caricaturizado del horror observado por Drácula. Todas las imágenes evocan acontecimientos en relación con la dictadura. La primera página presenta 
al héroe con anteojos de sol paseando por las calles de una ciudad X. Pero los signos que anclan la historia en un contexto contemporá- neo comienzan a develarse: un afiche con el rostro de un dictador con la palabra "papá". La viñeta siguiente muestra una mujer, saliendo de una carnicería llamada "el carnicero del pueblo", con una pierna humana en la mano. Finalmente, vemos a un niño comiendo tripas de perro y la inscripción "Dios nos ama" sobre un muro de fondo. Las referencias a la tortura, muerte y participación de sectores de la Iglesia en la dictadura se entreven rá- pidamente. La plancha siguiente desarrolla una secuencia de una manifestación popular, pidiendo paz en el territorio (Ver Figura 1). Distinguimos al fondo la Casa Rosada. Los militares por su parte discuten su situación y uno de ellos ordena reprimir a los manifestantes. En tanto éste personaje grita con su gran boca abierta, manchas rojas "salen" de ésta, símbolo de la sangre de los ciudadanos. Las imágenes de soldados abriendo fuego sobre los manifestantes, que son masacrados, se muestran en la plancha siguiente, que también nos presenta un Drácula bañado en sangre que observa con sorpresa, para luego emprender la fuga. En la plancha 4, Drácula recorre un cementerio y sobre el muro aparece la inscripción NN. En el interior, varias tumbas llevan la misma inscripción, referencia directa a los desaparecidos, pero esta vez como una inversión respecto de la realidad, en la que hay nombre y no hay cuerpo. Aparecen también retratadas las Madres de Plaza de Mayo y una cruda escena de tortura con picana eléctrica. La sonrisa de satisfacción de los verdugos pone en imágenes el sadismo de los responsables del plan sistemático del terror. Lo satírico se implanta entonces en la mostración grotesca de los fragmentos de cuerpo, la sangre, la brutalidad de una historia real, que se articula con la historia fantástica de Drá- cula, cuyo mito de origen -el de Vlad Tepes- es también sangriento. Lo mas notable en las historias, y que revela el enfoque paródico, es el hecho de que el mismísimo Drácula, que bebe sangre humana para alimentarse, parece desconcertado en ese regadero de sangre, en tanto se pasea entre la desolación y el horror. Secuencia tras secuencia, él parece mas y mas asqueado y disgustado, y claramente decepcionado de la realidad que descubre.

En tanto Drácula continúa mudo a lo largo de todas las secuencias, la ironía se manifiesta en lo caricatural, como en el contrapunto que emerge de la contradicción entre imágenes y palabras escritas en los carteles y paredes en el interior de las viñetas. Hay varios ejemplos ya evocados, como el afiche del dictador-papá, el carnicero del pueblo y la inscripción "Dios nos ama". Asimismo, la manifestación por la paz que es replicada con violencia, el NN y finalmente, la escena de un barrio pobre en que un cura da de comer a los habitantes. El afiche del muro es elocuente: "Todo va mejor con Coca Cola". Se utiliza aquí el slogan real de la publicidad de la bebida símbolo del capitalismo y el neocolonialismo estadounidense, y manifiesta tanto la pobreza y precariedad en Argentina, como las consignas de la dictadura, su propaganda, su corrupción y sus medidas neoliberales. Las palabras y las imágenes son tan grotescas porque sintéticas, abreviadas al punto de devenir ridículas, desmembradas como pedazos de cuerpos que aparecen acá y allá en la secuencia. Mencionemos también la transposición de los cuentos de hadas de los Hermanos Grimm, especialmente "Blancanieves" (Ver Figura 2), que asume dos dimensiones, la ironía en la lectura del texto-fuente y la sátira que apunta a personajes y circunstancias del contexto histórico. Esta transposición es de algún modo mas insólita que otras, por un lado, ya que el texto-fuente apunta originalmente al público infantil. Por otro lado, la presencia de caricaturas de figuras públicas de la realidad interpela al lector que comparte esas referencias. Igual que Drácula, Blancanieves constituye tanto un texto como un personaje largamente retomado sobre varios soportes y que toma bajo la mirada de Breccia matices macabros.

La historieta sigue el orden de la historia escrita por los hermanos Grimm pero, como en Drácula, recurre a imágenes y símbolos sintéticos, simplificados al extremo, lo que pone en evidencia la distancia critica de la 
ironía. Los personajes y decorados, construidos en parte por pedazos de papel y de fotos ensamblados con la técnica del collage, son fragmentados dentro de un espacio plástico aplanado y caótico.

Una vez mas, la distancia y la contradicción irónica entre la palabra y la imagen aparecen en ciertas secuencias, por ejemplo cuando la reina se disfraza para matar a la heroína ofreciéndole una manzana roja. Mientras los cartuchos de texto describen su disfraz de pobre granjera, la imagen la muestra disfrazada de granjero mejicano, con su sombrero y su grandes bigotes. Por otra parte, cuando Blancanieves llega a la casa de los enanos, éstos son representados a través de caricaturas de personajes ficticios y reales. La referencia interna a la historieta y a los medios está asegurada por Yellow Kid, Corto Maltese, etc., algunas referencias a Argentina y también se hace presente Napoleón Bonaparte. El príncipe se encarna en una suerte de malevo, que llega en un auto de los años 1930. Cuando éste encuentra a Blancanieves, nos damos cuenta de que ella no está muerta por influencia de un hechizo, sino ahogada por un pedazo de manzana, que sale despedido de su garganta cuando el príncipe se acerca. Breccia crea de este modo una escena cómica, lejos del beso de amor eterno que tantas transposiciones de este relato han evocado. Lo que hace reír aquí es precisamente la referencia y el contraste entre las dos situaciones, lo ridículo de la comparación entre un beso de amor romántico y un rechazo burlesco y la manera en que la transposición se burla creando una situación inverosímil.

En Blancanieves como en Drácula, la ironía aparece en la caricatura, las contradicciones manifiestas entre palabras e imágenes y la simplificación burlona de la situación. Asimismo, los elementos plásticos llevan ellos mismos una paradoja siendo que el carácter sombrío de las historias es puesto en imágenes con colores saturados y atmósferas coloridas y luminosas. Es decir que el aspecto siniestro es transpuesto por climas cromáticos asociados a circunstancias alegres. Se trata de un posicionamiento de Breccia que busca dibujar la fealdad con los medios de la caricatura, lo grotesco, pero con un tono alegre y burlón: lo siniestro se vuelve aún mas siniestro en vivos colores.

Parodia, sátira y la caricatura: las figuras grotescas

La obra transpositiva de Breccia se caracteriza de manera general por un cierto exceso de materia y de formas, específicamente en la representación de los personajes y sus rostros, en los cuales el dibujante trabaja en la estilización, la exageración, el agrandamiento de ciertos rasgos, en un modo caricatural. Ese carácter a veces torpe o de boceto de las figuras, que las lleva al lado risible, se articula y contrasta con el oscuro clima de las historias. Las figuras grotescas que Breccia crea en pos de visualizar el costado desmesurado, casi sublime de ciertas historias se volvieron un elemento identificable en su imagen. Las figuras son deformadas en muchos grados en su obra en blanco y negro, así como en las de color.

En Acuérdate (Ver Figura 3) del escritor mejicano Juan Rulfo, con guión de Juan Sasturain, las figuras están formadas por pequeños pedazos de plano blanco sobre un fondo negro: se forman por la articulación de planos yuxtapuestos, que crean por ejemplo rostros exuberantes con grandes bocas y ojos, rasgos muy contundentes que transmiten una cierta angustia en los personajes. Las formas son sistemáticamente fragmentadas, construidas por esos pequeños trozos que se disuelven en el fondo. Los cuerpos se forman de esos peque- ños fragmentos como cortados a cuchillo, como si las cabezas hubieran sido masticadas y escupidas. La misma configuración aparece en muchas otras de sus historietas. En Drácula y en El gato negro (transposición del cuento de Edgar Allan Poe), es esta vez el color que se vuelve totalmente pictórico, las formas manteniendo un acabado grosero y caricatural. La necesidad de Breccia de construir fragmentariamente sus figuras y darles un 
aspecto grotesco proviene de su representación del mundo como un lugar hostil y oscuro y de un posicionamiento irónico. Lo maravilloso de su obra, es que se puede ver cómo él mismo logra reír de sí mismo y de su circunstancia. Sin embargo, una humana mezcla de risa y de desesperación se encuentra latente, siempre, detrás de sus imágenes.

Notas

1. Dupriez, B. (1984). Gradus: les procédés littéraires (diccionario). Paris: Union générale d'édition. p. 331.

2. Bergson, H. (1964). Le rire: essai sur la signification du comique. Paris: PUF. p. 2.

3. Sasturain, J. (2013). Breccia, el Viejo. Conversaciones con Juan Sasturain. Buenos Aires: Colihue. p. 242.

4. Sasturain, J. (2013). Breccia, el Viejo. Conversaciones con Juan Sasturain. op. cit., p. 242.

5. Hutcheon, L. (1985). A Theory of parody: the teachings of twentieth-century art forms. New York: Methuen. p. 31.

6. Sangsue, D. (1994). La parodie. Paris: Hachette. p. 22.

7. Sangsue, D. (2007). La relation parodique. Paris: J. Corti. p. 243.

8. Duval, S.; Martinez, M. (2000). La satire: littératures française et anglaise. Paris: A. Colin, p. 29.

Bibliografía

Fuentes primarias 1 : transposiciones de Breccia

Breccia, A. (2011). Edgar Allan Poe. El gato negro y otras historias. Buenos Aires: Doedytores.

Breccia, A. (2008). Los Mitos de Cthulhu. Buenos Aires: Doedytores.

Breccia, A. (2006).

Breccia Negro. Version 2.0. Buenos Aires: Doedytores.

Breccia, A. (1993). Dracula, Dracul, Vlad ? Bah... Ginebra: Les Humanoïdes Associés.

Breccia, A.; Oesterheld H. (1982). Mort Cinder. Grenoble: Glénat.

Trillo, C.; Breccia, A. (2013). Había otra vez... El lado oscuro de los cuentos infantiles. Buenos Aires: Doedytores.

Fuentes primarias 2 : textos literarios

Hermanos Grimm (1937). Contes de Grimm. Paris: Nelson. 
Poe, E. A. (2008). Nouvelles histoires extraordinaires. Paris: Flammarion.

Stoker, B. (1912). Dracula. Londres: W. Rider and son.

Obras citadas, artículos consultados

Bakhtine, M. (1984). Esthétique de la création verbale. Paris: Gallimard.

Bergson, H. (1964). Le rire: essai sur la signification du comique. Paris: PUF.

Breccia, A.; Imparato, L. (1992). Ombres et lumières: conversations avec Latino Imparato. Paris: Vertige graphic.

Dupriez, B. (1984). Gradus: les procédés littéraires. Paris: Union générale d'édition.

Genette, G. (1987). Seuils. Paris: Seuil.

Groensteen, T.; Van Belle, A.; Dellisse, L.; Croix, A. De La; Coma, J.; Lecigne, B. (4/1985). "Dossier Alberto Breccia", Cahiers de la bande dessinée. $n^{\circ} 62$.

Hutcheon, L. (1985). A Theory of parody: the teachings of twentieth-century art forms. New York: Methuen.

Lovecraft, H. P. (1985). Épouvante et surnaturel en littérature. Paris: C. Bourgois.

Marin, L. (1978). Le récit est un piège. Paris: Minuit.

Sangsue, D. (1994). La parodie. Paris: Hachette.

Sangsue, D. (2008). La relation parodique. Paris: J. Corti.

Sasturain, J. (2013). Breccia, el Viejo. Conversaciones con Juan Sasturain. Buenos Aires: Colihue.

Smolderen, T. (2009). Naissances de la bande dessinée: de William Hogarth à Winsor McCay. Paris: Les Impressions nouvelles.

Todorov, T. Introduction à la littérature fantastique. Paris: Seuil.

Abstract: This article proposes some clues to analyze certain generic aspects of Alberto Breccia's transposable work. Specifically, it deals with the way in which the author, on the basis of thematic elements of the fantastic, makes a parodic and satirical movement. The cut made in the corpus of his work highlights those comic strips resulting from a transposition of literary stories to the comic strip. The concept of genre extends in turn from literature to other devices, such as comics, allowing us to place these works (and not only the literary texts that inspire them) within the fantastic and the wonderful. Breccia operates in his work a transposition of the fantastic to the image, this genre being a common denominator of his transpositive work.

Key words: Alberto Breccia - transposition - fantastic - satire. 
Resumo: Este artigo propõe algumas pistas de análise de certos aspectos genéricos do trabalho de transposição de Alberto Breccia. Especificamente, trata da maneira como o autor, com base em elementos temáticos do fantástico, faz um movimento paródico e satírico. O corte feito no corpus de seu trabalho destaca as tiras de quadrinhos resultantes de uma transposição de histórias literárias para a historieta. O conceito de gênero se prolonga da literatura para outros dispositivos, como os quadrinhos, permitindo colocar essas obras (e não apenas os textos literários que as inspiram) dentro do fantástico e maravilhoso. Breccia opera em seu trabalho uma transposição do fantástico para a imagem, sendo esse gênero um denominador comum de seu trabalho transpositivo.

Palavras chave: Alberto Breccia - transposição - fantástica - sátira.

[Las traducciones de los abstracts al inglés y portugués fueron supervisadas por el autor de cada artículo]

La parodia y la sátira en la historieta transpositiva de Alberto Breccia fue publicado de la página 33 a página42 en Cuadernos del Centro de Estudios de Diseño y Comunicación №74 